Ethiopian Journal of Environmental Studies \& Management 9 (1): 01 - 13, 2016.

ISSN:1998-0507

doi: http://dx.doi.org/10.4314/ejesm.v9i1.1

Submitted: November 20, 2014

Accepted: December 30, 2015

\title{
A COMPARATIVE STUDY OF MICROBIOLOGICAL AND PHYSICOCHEMICAL CHARACTERISTICS OF WATER DISTRIBUTED FROM TWO WATER TREATMENT PLANTS IN RWANDA
}

\author{
*RUTANGA, J.P. AND NIYIGENA, R. \\ University of Rwanda, College of Science and Technology (CST), Faculty of Science and \\ Technology, Department of Biology B.P 3900 Kigali Rwanda
}

\begin{abstract}
This paper presents an assessment of water quality distributed from two Rwandan Water and Sanitation Corporation Itd (WASAC) water branches: Kimisagara WASAC water treatment plant and Kizanye WASAC station in Kigali-Rwanda. Water samples collected from those two WASAC water stations were assessed for both microbiological and physicochemical quality (temperature, odor, color and $\mathrm{pH}$ ) using standard methods. A total of 32 samples were obtained from those stations. At the first sampling, 9 samples from homes supplied by Kizanye water station and 1 sample from its source were analyzed. Following their physicochemical records, their $\mathrm{pH}$ values (at $25^{\circ} \mathrm{C}$ ) ranged from 6.61 to 7.01 , temperatures ranging from 28 to $30^{\circ} \mathrm{C}$, while their turbidity ranged from 1.34 to $4.9 \mathrm{NTU}$. The $M P N$ count ranges from 0.9 to $14 \mathrm{MPN} / 100 \mathrm{ml}$. whereas regarding their microbiological assessment, fecal coliform counts on EMB agar plate ranged between $3.3 \times 10^{2}$ and $11.8 \times 10^{2}$ $\mathrm{cfu} / \mathrm{ml}$. The 9 samples from homes supplied by Kimisagara water treatment plant and 1 sample on its source were analyzed. Result of physicochemical analysis from Kimisagara plant showed that $\mathrm{pH}$ ranged from 7.53 to 7.00 while temperature and turbidity values ranged from 25 to $28^{\circ} \mathrm{C}$ and 0.70 to $14.09^{\circ} \mathrm{C}$ respectively. The MPN count ranges from 1.1 to $17 \mathrm{MPN} / 100 \mathrm{ml}$. The fecal coliform counts on EMB agar plate ranged between 0 to $17.8 \times 10^{2}$ $\mathrm{cfu} / \mathrm{ml}$. Specific bacteria were isolated and then identified as Escherchia coli, Enterobacter aerogenes and Klebsiella species. Although Kimisagara and Kizanye water sources meet physicochemical and microbiological standard parameters, almost 50\% of their destinations were found falling out of these standard parameters. Thus, as recommendation to WASAC authority, there is a need for improvement in the water management strategy for better water quality especially along the distribution network.
\end{abstract}

Key Words: Microbiological analysis, physicochemical analysis, coliforms, Most Probable Number, water treatment, WASAC.

\section{Introduction}

Water is one of the most abundant resources on which life on earth depends; in some places, availability of water is critical, limited and renewable (Urbansky and Magnuson, 2002). Water plays a vital role in the proper functioning of the earth's ecosystem. Shortage of water could lead to

*Corresponding Author: Rutanga, J.P.

Email: jeanrutanga@yahoo.fr 
disease outbreak and economic loss; hence water is a necessity, it is a unique liquid and without it life is impossible. Man uses water for various purposes which include drinking, transportation, industrial and domestic use, irrigation in agriculture, recreation, fisheries, and waste disposal among others (Ajayi and Akonai, 2005). Water that is of a good drinking quality is important to human physiology, and man's continued existence depends so much on its availability (Lamikanra, 1999; FAO, 1997). The quality of water for drinking deteriorates due to inadequacy of treatment plants, direct discharge of untreated sewage into rivers and stream, and inefficiency of piped water distribution system (UNEP, 2001). The contaminated water therefore has critical impact on all biotic components of the ecosystem and this could affect its use for other purposes.

Water receives its bacteria spores from air, sewage, organic waste, dead plants and animal; at times almost all microorganisms may be found in water, but bacteria appeared to be the major water pollutants (Peter and George., 1989). Water obtained from wells, boreholes, streams and river are never chemically pure, even rain water contains dissolved materials from the air as well as suspended dust intermixed with microorganisms (Prescott et al., 2008). To test water purity, microbiological examination as well as physical and chemical analysis are performed. Microbiological examination is usually intended to identify water sources which have been contaminated with potential disease-causing microorganisms. Such contamination generally occurs either through improperly treated sewage or improperly functioning sewage treatment system. Chemical analysis can however determine whether water is polluted and provide other useful information (APHA, 1998).
In many developing countries like Rwanda, availability of water has become a critical and urgent problem and it is a matter of great concern to families and communities (Moyo et al., 2004). Therefore, periodic monitoring of water quality is very important because of its capacity to spread diseases within a large population (UNEP, 2011).

In Rwanda, population is still experiencing various problems due to the consumption of unsafe water (RBS, 2011). In an annual report published by Rwanda Bureau of Standard (RBS) in 2011, the likelihood of other contaminants being present in drinking water has been mentioned. For example, low $\mathrm{pH}$, a measure of the acidity of water, this may lead to corrosion of plumbing and water supply (UNEP, 2011).

Therefore, a good knowledge of the chemical quality of raw water is necessary so as to guide its suitability for use. Thus, regular physicochemical analysis of water at source must be carried out to determine and check the effectiveness of its treatment process. As a matter of fact, a study of analyzing the physicochemical and microbial characteristics of water has been chosen to assess and ensure the quality of water distributed in Kimisagara sector; from Kimisagara water treatment plant and Kizanye WASAC water station. The main objective of our study was to study and compare microbiological and physicochemical characteristics of water distributed from Kimisagara water treatment plant and Kizanye WASAC station. The specific objectives were: To identify microorganisms found in water collected from Kimisagara water treatment plant and Kizanye station, to highlight the physicochemical characteristics of water distributed from Kimisagara water treatment plant and Kizanye water station and to compare microbiological and 
physicochemical characteristics of water distributed from both Kimisagara water treatment plant and Kizanye water station with the international standards of water quality.

\section{Material and Methods \\ Sample Collection}

Water samples were collected from homes supplied by Kimisagara WASAC water treatment plant and Kizanye WASAC water station. Samples were obtained as follows: For both study areas (Kizanye water station and Kimisagara water treatment plant) at the source, water samples were taken in filters once ready to be distributed. At their destinations (homes), water was allowed to flow out for 2 minutes (to make sure that the collected water sample is homogeneous and is not contaminated with the tap contaminants) before samples were collected.

All samples were taken and kept in sterile sampling bottles before they were transported to Kigali Institute of Science and Technology KIST's biology laboratory for further analysis.

\section{Physicochemical analysis \\ pH readings}

The $\mathrm{pH}$ of the collected samples was determined in Kist's laboratory using the pH meter (PHYWE Systeme GMBH).

\section{Temperature}

A simple thermometer in centigrade scale (500, 0.5 divisions) was used to measure the water temperature of each sample. The thermometer was inserted into water sources to determine their temperature values.

\section{Turbidity}

Turbidity in water samples was measured with turbidity meter (PHYWE).
Microbiological Analysis

Enumeration and detection of bacteria by applying the most probable number (MPN) method

This was done accordingly as recommended by standard method for isolating E.coli (APHA, 1998). Materials and media used for the analysis consisted of the following: fermentation tubes with aluminum caps, Durham tubes, MacConkey broth, inoculating loop, Bunsen burner, syringes (10, 5 and $2 \mathrm{ml}$ ). According to the standard methods committee, it is done in three steps: first presumptive test followed by confirmed test and completed test (https://www.norweco.com/html/lab/test methods/9221bfp.htm)

The most probable number tube fermentation technique was performed in three stages: Presumptive test, confirmative test and completed test (Roberts et al., 1995).

\section{Presumptive Tests}

Each sample was distributed in 15 tubes containing lactose. Using sterile pipettes, $1 \mathrm{ml}$ of sampled water was dispensed into two sets of 5 tubes containing $10 \mathrm{ml}$ of sterile single strength lactose broth: $10 \mathrm{ml}$ of each sample were also dispensed into a set of test tubes containing $10 \mathrm{ml}$ of sterile lactose broth; and $0.1 \mathrm{ml}$ also was added to a set of 5 tubes containing $10 \mathrm{ml}$ of lactose broth (http://www.rpi.edu/dept/chemeng/Biotech Environ/Environmental/WATER/presumpt ive.html)

\section{Confirmative Tests}

A loop full of the sample from positive tubes were transferred into a plate containing Eosine Methylene blue agar (EMB) by streaking method and incubated at $37^{\circ} \mathrm{C}$ for 24 to 48 hours. The agar inhibits gram positive organisms and allows the gram negative coliforms to grow. Coliforms produce colonies with 
dark centers, green metallic sheen and large pinkish colonies.

\section{The Completed Tests}

Organisms that grew on the confirmed test media were inoculated into nutrient agar plates and tubes of MacConkey broth. After incubation at $37^{\circ} \mathrm{C}$ for $24 \mathrm{~h}$, the broth was checked for production of gas and a Gram staining was performed for organisms on the nutrient agar plates (Roberts et al., 1995). A positive test indicated that coliforms were present in sampled water when the tests showed gram negative, non spore- forming rod with gas production on MacConkey broth.

\section{Results and Discussion}

The physicochemical properties of the freshly collected water samples were presented using tables. Some of the potable water samples, particularly those taken from the sources, did not comply with the standard limits for drinking water and waste discharges. Turbidity was observed to increase if the color of the water changes from colorless to light-yellowish.

Table 1: Physicochemical characteristics of water sampled from Kizanye WASAC water station and homes

\begin{tabular}{|c|c|c|c|c|c|}
\hline Type of sample & Turbidity (NTU) & $\mathrm{pH}$ & Temperature $\left({ }^{\circ} \mathrm{C}\right)$ & Odor & Color \\
\hline $\begin{array}{l}\text { Kizanye WASAC } \\
\text { water station }\end{array}$ & 01.34 & 6.95 & 28.00 & Odorless & Colorless \\
\hline Home 1 & 1.94 & 7 & 28.00 & Odorless & Colorless \\
\hline Home 2 & 2.03 & 6.9 & 30.00 & Odorless & Colorless \\
\hline Home 3 & 3.07 & 6.84 & 30.00 & Odorless & Colorless \\
\hline Home 4 & 3.06 & 6.77 & 28 & Odorless & Colorless \\
\hline Home 5 & 4.09 & 6.80 & 28.50 & Odorless & Colorless \\
\hline Home 6 & 4.9 & 6.73 & 28.00 & Odorless & Colorless \\
\hline Home 7 & 3.01 & 6.75 & 28 & Odorless & Colorless \\
\hline Home 8 & 4.07 & 6.61 & 28 & Odorless & Colorless \\
\hline Home 9 & 3.09 & 7.01 & 28 & Odorless & Colorless \\
\hline
\end{tabular}

The results in Table 1 show that $\mathrm{pH}$ on Kizanye WASAC station ranged from 6.67 to 7.01 and the turbidity ranged from 01.34 to 4.9. All samples were odorless and colorless. Comparing Kizanye station water (source) and its destinations (homes), $\mathrm{P}^{\mathrm{H}}$ was almost constant whereas the turbidity increased from source to homes.

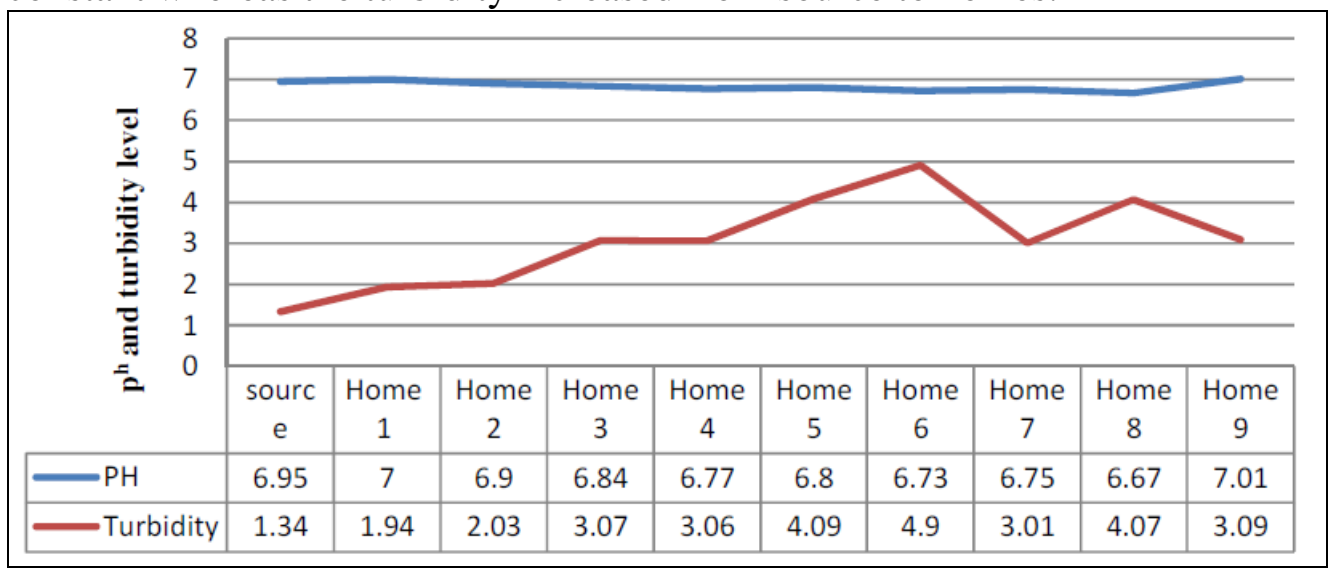

Figure 1: $\mathrm{pH}$ and turbidity variation on samples collected from Kizanye water station and homes 
Considering $\mathrm{pH}$ of all collected water samples, apart from the last home (home 9), the rest had less $\mathrm{pH}$ values than that at the source. The $\mathrm{pH}$ was almost constant, because it only varied from 6.95 to 6.67 . The turbidity varied greatly and most of the samples collected far from the source had a high turbidity. The turbidity on the source was $1.34 \mathrm{NTU}$ and was the smallest whereas home 6 had the highest with 4.9 NTU.

On the $12^{\text {th }}$ May, 2012, a number of 10 water samples were collected: 1 sample at Kimisagara WASAC water treatment plant and 9 samples at 9 randomly selected homes. They were all analysed for their physicochemical characteristics: $\mathrm{P}^{\mathrm{H}}$, turbidity, temperature, color and odor.

Table 2: Physicochemical characteristics of Kimisagara water treatment plant and homes' water samples

\begin{tabular}{llllll}
\hline Homes and source & Turbidity & $\mathrm{pH}$ & Temperature & Odor & Color \\
\hline Kimisagara Water treatment & 0.70 & 7.5 & 28 & Odorless & Colorless \\
Home 1 & 1.94 & 7.53 & 27 & Odorless & Colorless \\
Home 2 & 2.03 & 7.40 & 28 & Odorless & Colorless \\
Home 3 & 7.07 & 7.40 & 28 & Odorless & Colorless \\
Home 4 & 7.06 & 7.34 & 28 & Odorless & Colorless \\
Home 5 & 14.09 & 7.23 & 28 & Odorless & Light yellowish \\
Home 6 & 6.9 & 7.40 & 28 & Odorless & Colorless \\
Home 7 & 5.00 & 7.33 & 28 & Odorless & Colorless \\
Home 8 & 4.00 & 7.35 & 29 & Odorless & Colorless \\
Home 9 & 9.01 & 7.00 & 28 & Odorless & Colorless \\
\hline
\end{tabular}

From Table 2, the recorded $\mathrm{pH}$ for Kimisagara water treatment plant (source) and home samples ranged from 7.00 to 7.53. One sample had a light yellowish color (home 5) and the highest turbidity
(14.09) whereas others were colorless. All samples were odorless and their temperature ranged from $27{ }^{\circ} \mathrm{C}$ to $29{ }^{\circ} \mathrm{C}$. The $\mathrm{pH}$ was almost constant whereas the turbidity varied significantly.

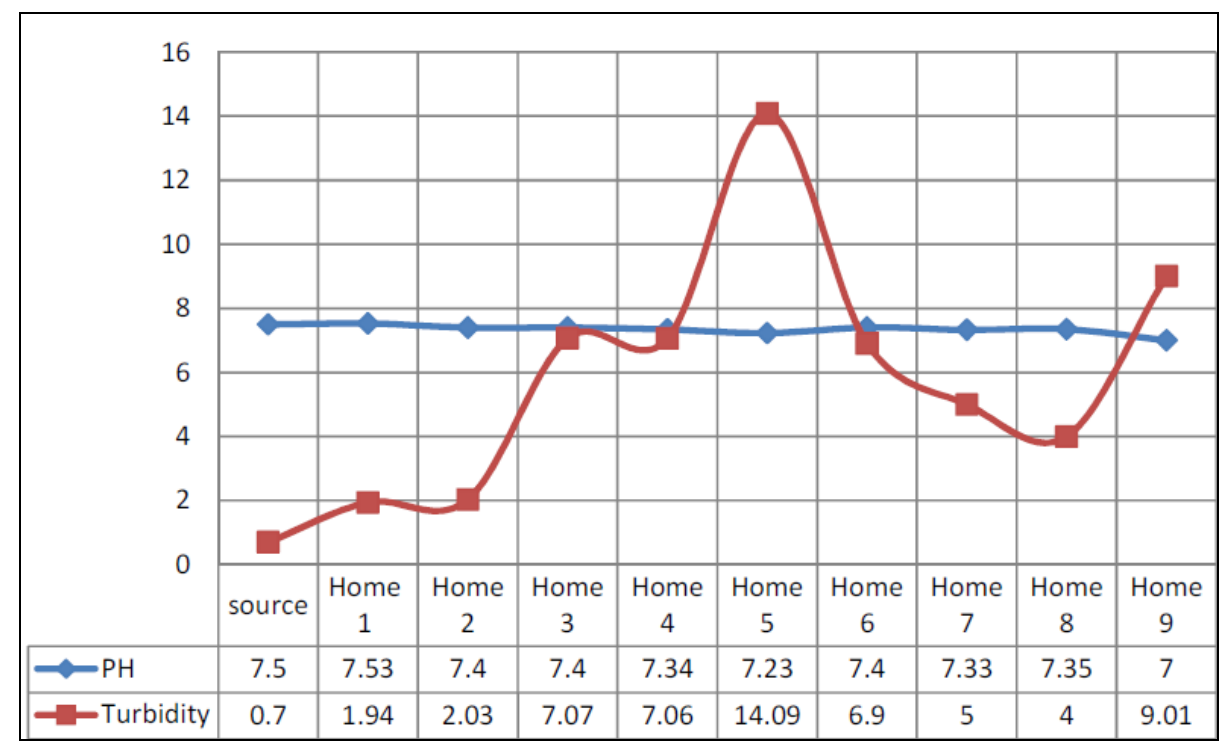

Figure 2: $\mathrm{pH}$ and turbidity variation on samples sampled from Kimisagara water treatment plant and its supplied homes. 
As indicated in Figure 2, the $\mathrm{pH}$ changed of $0.4 \mathrm{pH}$ units. The turbidity changed a lot, as from 0.7 to 14.09 NTU. Five of the nine selected homes had a level of turbidity greater than $5 \mathrm{NTU}$, and this falls out of WHO and WASAC standards. Those homes are: home 3, home 4, home 5 , home 6 , and home 9 .

To compare water quality at Kimisagara water treatment plant and Kizanye water station, we decided to collect their respective water samples on the same day (May 25, 2012), as they were all sharing same various whether and climate parameters. There were 12 samples collected in total, 10 samples from homes supplied by those two WASAC stations ( 5 samples at each) and one sample at each WASAC branch (Kimisagara water treatment plant and Kizanye water station). All collected samples were assessed for their physicochemical characteristics: turbidity, $\mathrm{p}^{\mathrm{H}}$, temperature, odor and color.

Table 3: Comparison of physicochemical characteristics of water samples collected at Kimisagara water treatment plant, Kizanye water station and their respective supplied homes

\begin{tabular}{|c|c|c|c|c|c|}
\hline \multicolumn{6}{|c|}{ Kizanye WASAC water station } \\
\hline Water sample & Turbidity & $\mathrm{P}^{\mathrm{H}}$ & Temperature & Odor & Color \\
\hline Source & 1.42 & 6.83 & 28.00 & Odorless & Colorless \\
\hline Home 1 & 1.94 & 6.8 & 28.00 & Odorless & Colorless \\
\hline Home 2 & 2.01 & 6.80 & 28.00 & Odorless & Colorless \\
\hline Home 3 & 2.07 & 6.5 & 27.00 & Odorless & Colorless \\
\hline Home 4 & 2.03 & 6.74 & 29.00 & Odorless & Colorless \\
\hline Home 5 & 2.09 & 6.63 & 28.00 & Odorless & Colorless \\
\hline \multicolumn{6}{|c|}{ Kimisagara water treatment plant } \\
\hline Source & 1.94 & 7.5 & 28.00 & Odorless & Colorless \\
\hline Home 1 & 2.03 & 7.3 & 28.00 & Odorless & Colorless \\
\hline Home 2 & 4.07 & 7.3 & 28.00 & Odorless & Colorless \\
\hline Home 3 & 7.06 & 7.34 & 27.00 & Odorless & Colorless \\
\hline Home 4 & 7.99 & 7.33 & 28.00 & Odorless & Colorless \\
\hline Home 5 & 7.80 & 7.47 & 28.00 & Odorless & Colorless \\
\hline
\end{tabular}

As indicated in Table 3, pH on Kizanye water station was 6.83 whereas the $\mathrm{pH}$ on Kimisagara water treatment plant was 7.5. The turbidity on Kizanye water station was in 1.42-2.09 range whereas that of samples collected from Kimisagara water treatment plant ranged between 1.94 and 7.99. All samples were odorless and colorless.

The $\mathrm{pH}$ of samples collected from Kimisagara water treatment plant supplied homes was higher than the $\mathrm{pH}$ of samples collected from Kizanye water station supplied homes. 


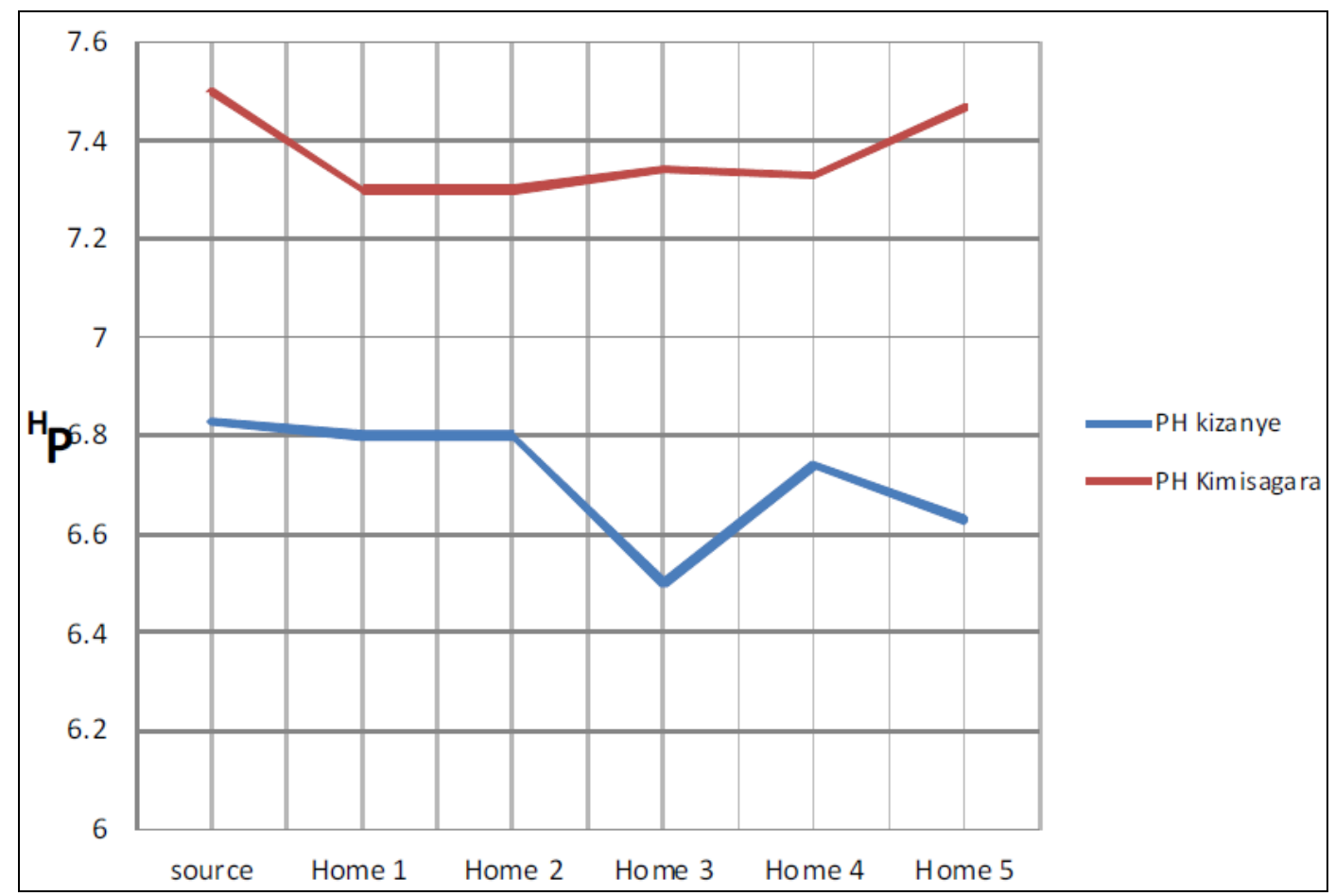

Figure 3: $\mathrm{pH}$ variation on samples collected from Kimisagara water treatment plant and Kizanye water station sources and supplied homes

As shown in Figure 3, the $\mathrm{pH}$ from Kimisagara water treatment plant and its destinations (homes) was higher than the $\mathrm{pH}$ from Kizanye and its destinations. One home (home 3) had a $\mathrm{pH}$ of 6.5 and was almost going to fall under the standard range, 6.5 to 8.5 as WHO reports.
The turbidity of samples collected from Kizanye water station was almost constant whereas the turbidity of water samples collected from Kimisagara treatment plant increased considerably from the source (treatment plant) to its destinations (homes). 


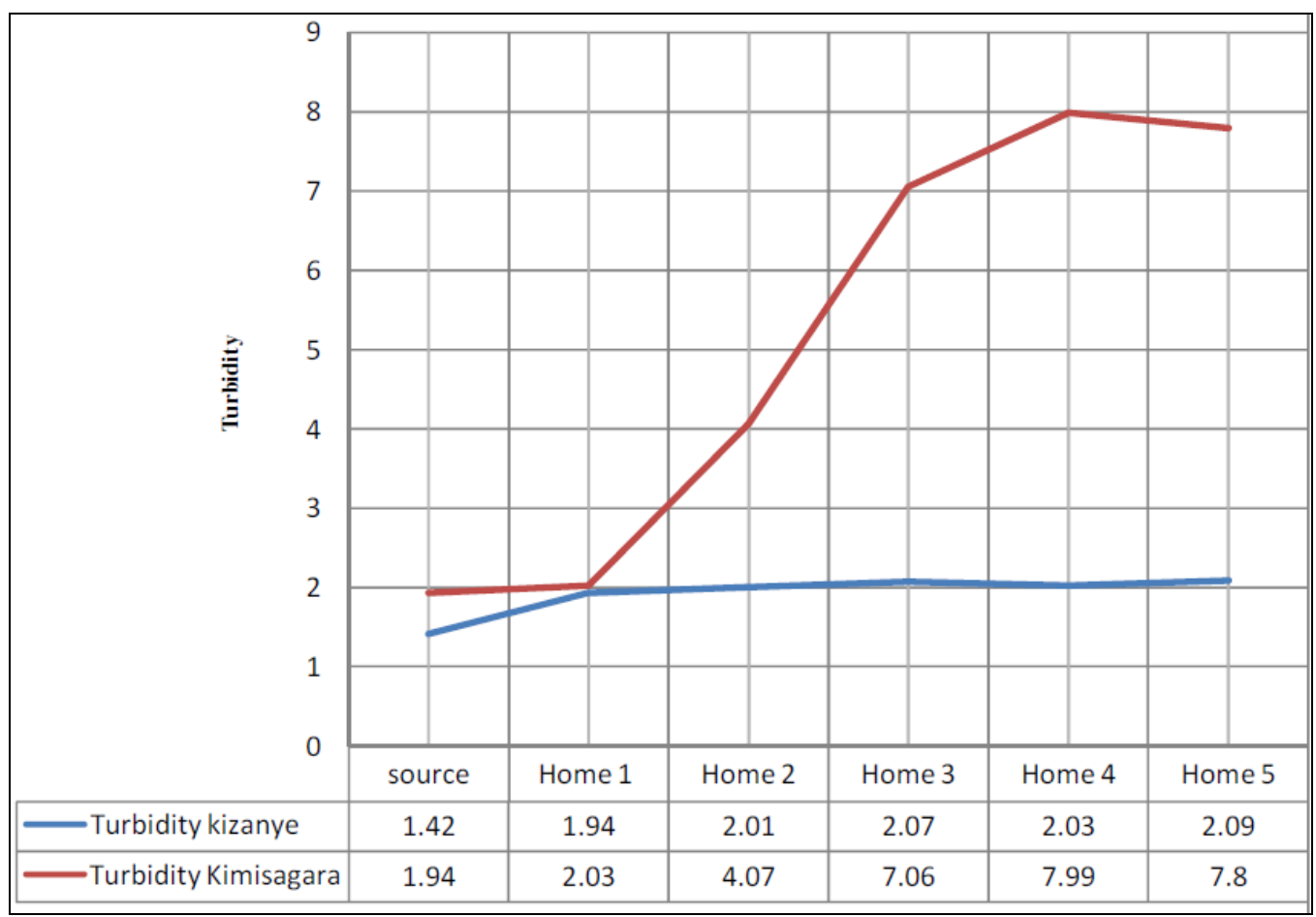

Figure 4: Turbidity variation on samples collected from Kimisagara water treatment plant, Kizanye water station and their supplied homes

The source of Kizanye (Kizanye water station) and its five selected destinations (homes) had standard turbidity for drinking water (less than 5 NTU). Whereas, three of five homes selected from Kimisagara water treatment plant had a higher turbidity (more than $5 \mathrm{NTU}$ ). This is dangerous to the three households as WHO suggest that the appearance of water with a turbidity of more than $5 \mathrm{NTU}$ is not acceptable to consumers (WHO, 1998).

The physicochemical analysis of both Kizanye water station and Kimisagara water treatment plant water samples indicated that water is contaminated on their routes (ways) from sources to their respective destinations (homes). This has been reported by a number of authors who have evidenced a statistically significant deterioration in the microbiological quality of water between the source and point of use in homes (Simango et al., 1992; Genthe et al., 1997). The assessed parameters at both Kimisagara water treatment plant and Kizanye water station fall in the standard ranges; but it was found different at almost $50 \%$ of their respective destinations (homes).

The turbidity measured for all samples from Kizanye water station ranged between 1.09 and 4.07 Nephelometric turbidity unit (NTU). According to WASAC, the maximum level of turbidity permitted in distribution is 5 NTU (WASAC, 2011). The turbidity recorded at the source (Kizanye water station) was less compared to others (01.34 NTU). World Health Organization suggests that the appearance of water with a turbidity of less than 5 NTU is usually acceptable to consumers. The consumption of highly turbid water may constitute a health risk as excessive turbidity can protect pathogenic microorganisms from the effects of disinfectants, and also stimulate the growth of bacteria during storage (WHO, 2006).

The $\mathrm{pH}$ values of most sampled water were slightly acidic (Table 1 and 4) 
compared to the standard range revealed by International Bottled Water Association (IBWA, 2004), which recommended water to be within 5-7 $\mathrm{P}^{\mathrm{H}}$ range. However, the guideline provided by WHO, which also fits with the WASAC's parameters (6.5 to $\left.8.5 \mathrm{P}^{\mathrm{H}}\right)$ was complied by all collected water samples. According to Medera et al. (1982), deviation from the neutral $\mathrm{P}^{\mathrm{H}}$ value of water 7.0 is a result of the $\mathrm{CO}_{2}$, carbonates and carbonate equilibrium.

On the third sampling at Kizanye water station, the fourth home has the lowest $\mathrm{P}^{\mathrm{H}}$ (6.83). The source of Kimisagara water treatment plant has the highest $\mathrm{P}^{\mathrm{H}}(7.5)$ and this is due to the addition of sodium bicarbonate during treatment, and this high $\mathrm{pH}$ results in taste complaints. The overall of the $\mathrm{P}^{\mathrm{H}}$ also shows that it decreases from source to homes. This can be also one reason to say that water in pipes is polluted by the Rwandan acidic soil as it has been confirmed by a study conducted by Centre for the environment, entrepreneurship and sustainable development (CEESD, 2010).

The temperature range varied between 27 and 30 centigrade degrees. This temperature range of water samples and the water body is believed to have been influenced by the intensity of the sunlight as temperature rose from $28^{0} \mathrm{C}-$ to $30^{\circ} \mathrm{C}$ on relatively hot days (Mulusky, 1974). All samples were odorless and only one sample showed to have a light yellowish color (see home five on Table 2). The holders of this home said that they receive such colored water since last year, especially during the rainy season. Pipes are under between houses so that it is difficult for their replacement and repair if necessary. However, WHO recommends that drinking water must be odorless and colorless (WHO, 2011).

The microbiological analysis results of collected water samples are shown in tables below. The most probable number (MPN) for the presumptive total coliform count of the water samples ranged from 0.93 to $13 \mathrm{MPN} / 100 \mathrm{ml}$ for Kizanye water station and from 0.93 to 17 for Kimisagara water treatment plant. The fecal coliform counts per $100 \mathrm{ml}$ of water samples on EMB agar plate ranged between null to 21 cells.

Results displayed under Table 4 below, were obtained after the analysis of 9 water samples collected from 9 homes supplied with Kizanye water station and one sample at the station itself.

Table 4: Microbiological characteristics of water samples collected at Kizanye water station and its supplying homes

\begin{tabular}{lll}
\hline Water sample & MPN/ $100 \mathrm{ml}$ & Coliform count on EMB $(\mathrm{CFU} / \mathrm{ml})$ \\
\hline Source & 0.93 & $3.3 \times 10^{2}$ \\
Home 1 & 1.1 & $4.9 \times 10^{2}$ \\
Home 2 & 1.1 & $4.8 \times 10^{2}$ \\
Home 3 & 1.7 & $3.6 \times 10^{2}$ \\
Home 4 & 14 & $5.7 \times 10^{2}$ \\
Home 5 & 1.7 & $11.8 \times 10^{2}$ \\
Home 6 & 2.2 & $5.8 \times 10^{2}$ \\
Home 7 & 2.2 & $8.1 \times 10^{2}$ \\
Home 8 & 2.7 & $7.9 \times 10^{2}$ \\
Home 9 & 13 & $7.2 \times 10^{2}$ \\
\hline
\end{tabular}


As it can be well noted from the Table 4 above, the highest coliform level recorded was $11.8 \times 10^{2} \mathrm{CFU} / \mathrm{ml}$ and the smallest was $3.3 \times 10^{2} \mathrm{CFU} / \mathrm{ml}$. This is a big challenge to the nine home holders as all collected samples from homes recorded more than $4 \mathrm{cfu} / 100 \mathrm{~mL}$ except home 3 ; and according to the Food Act 281(Food Act 1983), the colony count should never record more than $4 \mathrm{cfu} / 100 \mathrm{~mL}$ in drinking water.

Water samples from Kimisagara water treatment plant were assessed microbiologically as well. The following table shows the MPN and the number of colonies formed on the EMB medium (in $\mathrm{CFU} / \mathrm{ml}$ ).

Table 5: Microbial characteristics of water samples collected at Kimisagara water treatment plant and its supplying homes

\begin{tabular}{lll}
\hline Water sample & MPN/ 100ml & Coliforms count on EMB $(\mathrm{CFU} / \mathrm{ml})$ \\
\hline Source & 0.93 & less than 30 colonies \\
Home 1 & 1.1 & $5.8 \times 10^{2}$ \\
Home 2 & 1.1 & $4.4 \times 10^{2}$ \\
Home 3 & 1.7 & $3.6 \times 10^{2}$ \\
Home 4 & 14 & $16.3 \times 10^{2}$ \\
Home 5 & 17 & $13 \times 10^{2}$ \\
Home 6 & 2.2 & $3.9 \times 10^{2}$ \\
Home 7 & 2.2 & $4.2 \times 10^{2}$ \\
Home 8 & 2.7 & $14.5 \times 10^{2}$ \\
Home 9 & 13 & $17.8 \times 10^{2}$ \\
\hline
\end{tabular}

The table above (Table 5) shows us that samples collected far from the source are the most microbiologically polluted. On the first home sample, the coliforms on EMB were recorded as $5.8 \times 10^{2} \mathrm{CFU} / \mathrm{ml}$; whereas on the home 9 sample $17.8 \times 10^{2} \mathrm{CFU} / \mathrm{ml}$ were recorded. However other homes in the middle showed an increase of coliform units such as home 4 with $16.3 \times 10^{2}$ $\mathrm{CFU} / \mathrm{ml}$.

Below is a table showing microbiological analysis performed on the $25^{\text {th }}$ May, 2012, comparing Kizanye WASAC water station and Kimisagara WASAC water treatment plant.

Table 6: Comparison of microbial characteristics of water samples collected at Kimisagara WASAC water treatment plant and Kizanye WASAC water station as sources and their respective supplying home

\begin{tabular}{lll}
\hline Water sample & MPN/ 100ml & Coliforms count on EMB $(\mathrm{CFU} / \mathrm{ml})$ \\
\hline & Kizanye WASAC water station & \\
Source & 0.68 & less than 30 colonies. \\
Home 1 & 0.93 & $3.6 \times 10^{2}$ \\
Home 2 & 1.7 & less than 30 colonies. \\
Home 3 & 2.1 & $5.5 \times 10^{2}$ \\
Home 4 & 1.4 & $8.3 \times 10^{2}$ \\
Home 5 & 2.1 & $6.4 \times 10^{2}$ \\
\hline & Kimisagara WASAC water treatment station \\
Source & 1.4 & $3.3 \times 10^{2}$ \\
Home 1 & 1.7 & $4.0 \times 10^{2}$ \\
Home 2 & 1.7 & $14.1 \times 10^{2}$ \\
Home 3 & 2.6 & $4.7 \times 10^{2}$ \\
Home 4 & 3.3 & $15.4 \times 10^{2}$ \\
Home 5 & 2.1 & $5.0 \times 10^{2}$ \\
\hline
\end{tabular}


The MPN values ranged between 0.68 to 2.1 on Kizanye WASAC water station samples and from 1.4 to 3.3 on Kimisagara WASAC water treatment plant samples. On EMB (Eosin methylene blue agar) medium, there was formation of three characteristic colonies. The organisms that grew on the confirmed test media (EMB) were then inoculated into nutrient agar slants and tubes of MacConkey broth.

After incubation at $37^{\circ} \mathrm{C}$ for $24 \mathrm{~h}$, the broth was checked for production of gas and a Gram's stain was made from organisms on the nutrient agar slant. A positive test indicates coliforms present in the water sample when the tests showed Gram negative and non spore- forming rods when there a growth associated with a production of gas on MacConkey Broth. The isolated microorganisms were E.coli, Enterobacter Aerogenes and Klebsiella species.

Table 7: Morphological characteristics of the three isolated colonies

\begin{tabular}{cll}
\hline \multicolumn{1}{c}{ Isolates } & Morphological Characteristics & Organisms \\
\hline \multirow{3}{*}{ Colony 1} & Gram negative, circular, low convex, with & E.coli \\
& entire margin, mucoid, opaque, small, rod & \\
& shaped, pinkish glistering with metallic & \\
& sheen colony on Eosin Methylene Blue & \\
(EMB) agar. & & \\
Colony 2 & Large pinkish mucoid colonies, dark & Enterobacter Aerogenes \\
Colony 3 & centers, sometimes with metallic sheen. & \\
\hline
\end{tabular}

The total bacteria counts for most of the collected samples were generally high, exceeding the limit of $1.0 \times 10^{2} \mathrm{cfu} / \mathrm{ml}$ which is the standard limit of heterotrophic count for drinking water (EPA, 2002). Water on the sources fits the WHO microbiological standards. At Kizanye water station, the MPN was $0.93 / 100 \mathrm{ml}$ and at Kimisagara water treatment plant was $1.1 / 100 \mathrm{ml}$. Those results show that water at both sources (Kimisagara water treatment plant and Kizanye water station) is safe for drinking.

The most probable number (MPN) for the presumptive total coliform count of Kizanye water station samples ranged from 0.93 to $14 \mathrm{MPN} / 100 \mathrm{ml}$ (Table 4). The same results indicate that water from the source had the lowest total coliform counts of $0.93 \mathrm{MPN} / 100 \mathrm{ml}$ and the fourth home had the highest coliforms count of 14 MPN/100 ml.
The coliform count on EMB agar plate also showed that water from Kizanye water station should be considered safe, and is only chlorinated during treatment. The highest coliform level was $11.8 \times 10^{2}$ $\mathrm{cfu} / \mathrm{ml}$. Six of the selected homes had greater than 2MPN/100 $\mathrm{ml}$ which is the standard MPN/100ml according to FAO (FAO, 1997).

On the side of Kimisagara water treatment plant, as indicated in Table 5, the destinations far from the source are the most microbiologically polluted. At the first home, coliforms on EMB were recorded as $5.8 \times 10^{2} \mathrm{cfu} / \mathrm{ml}$, whereas on home 9 sample were $17.8 \times 10^{2} \mathrm{cfu} / \mathrm{ml}$. However other homes in the middle showed an increase of coliforms, like the fourth home with $16.3 \times 10^{2} \mathrm{cfu} / \mathrm{ml}$.

In a study conducted in piped water in Nigeria by Ajayi and Akonai, they stated that water pollution can be a result of 
climate change like high raining or a terrible wet season with sands and others small particles in the air which differ a day to another (Ajayi and Akonai, 2005). In six samples collected from Kizanye water station, the MPN ranged between 0.68 and 2.1/100ml; whereas, among six samples collected from Kimisagara water treatment plant, the MPN ranged from 1.4 to 3.3 MPN/100ml.

The overall observation of the results showed that sampled water samples at different randomly selected homes were unsafe for drinking. This is close to the experiment done by WHO in 2011, revealing that contamination of water in distribution systems is a main challenge to achieve the Millennium Development Goals (MDGs) to reduce by half the proportion of the world's population without sustainable access to safe drinking water and sanitation by 2015 (WHO, 2006). Currently, UNICEF and WHO estimate that 1.1 billion people lack access to improved water supplies and 2.6 billion people lack adequate sanitation.

\section{Conclusion and Recommendations}

Conclusively, our study showed that Kimisagara water treatment plant and Kizanye water station sources fit with the standard physicochemical and microbiological parameters. However, almost $50 \%$ of their destinations (supplied homes) fall out of these standard parameters. Thus, it is recommended that there should be a way of improving distribution systems from the above mentioned sources. Water should always meet different quality specifications depending on its particular uses.

Potable and domestic water should be harmless for the health of man and should have proper organoleptic properties and should be suitable for domestic use. The presence of E.coli and Enterobacter aeogenes in water samples collected from different homes indicated that conditions of distribution are not appropriated. Thus, Water quality should be controlled in order to minimize acute problem of water related diseases, which are endemic to the health of man. In homes, Water should be boiled for five to ten minutes to kill the disease causing bacteria. Alternatively, water could be treated with chlorine to kill bacteria.

It is significantly important to ensure the quality of water from the WASAC stations and treatment plants to their destinations (supplied homes). Therefore, it is recommended that treatment of water should be a matter of great concern to WASAC, communities, families and individuals using piped water in their dairy life because of the health hazard potential of contaminated water. This can be achieved by putting in place appropriate programs to educate population on the need to purify water and make it safe for drinking and other domestic purposes. Different measures for identification, control and elimination of water source contaminants should be considered. In addition, extra sub-water stations should be put in place to decrease the long way usually taken by water towards its destination (supplied homes). Assuming that water can also be contaminated due to the ageing of distributing pipes, we recommend that WASAC and Kimisagara population should always control the status of water pipes in order to repare or replace them in case needed.

\section{References}

Ajayi, A.O. and Akonai, K.A. (2005). Distribution pattern of enteric organisms in the Lagos Lagoon. African journal of biomedical research, 8(3): 163-168.

American Public Health Associated (APHA), (1998). Standard method for 
examination of water and waste water, 20th Ed. American Public Health Associated Inc, New York: American Water Work Associated (AWWA).

Environmental Protection Agency (EPA), (2002). Safe Drinking Water Act Amendment. Washington: EPA. Available at: <http://www.epa. Gov/safe/mcl/Html $>$ [Accessed on $29^{\text {th }}$ May 2012]

Energy Water and Sanitation Authority (WASAC), (2011). Water treatment and distribution at Kimisagara water treatment plant. Kigali: WASAC.

Food and Agriculture Organization (FAO) (1997). Chemical Analysis Manual for Food and Water. 5th Ed. ROME: FAO, pp. 20-26.

Centre for the environment, entrepreneurship and sustainable development (CEESD), (2010). Imidugudu project study components. <Available at: http://www.ceesd.nur.ac.rw/spip.php?a rticle9 $>$ [Accessed $1^{\text {st }}$ July 2012]

Food Act 1983. (Act 281) and regulations, (2003). Twenty-fifth Schedule standard for water and packaged drinking water. Malaysia: International Law Book services.

Genthe, B., Strauss, N., Yundule, C., Maforah, F. and Seager, J. ( 1997). The effect of type of water supply in a developing community in South Africa. Water Science Technology, 35(12): 35-40.

International Bottled Water Association (IBWA), (2004). Model Bottled Water Regulation. Alexandria: IBWA.

Lamikanra, A. (1999). Essential Microbiology for Students and Practitioners of Pharmacy: Medicine and Microbiology. $2^{\text {nd }}$ Edition. Lagos: Amkra books.
Moyo, S., Wright, J., Ndamba, J. and Gundry, S. (2004). Realising the maximum health benefits from water quality improvements in the home: A case from Zaka district, Zimbabwe. Physics and Chemistry of the Earth, 29(1):1295-1299.

Peter, H.R. and George, B.J. (1989). General Microbiology, Water Treatment. $2^{\text {nd }}$ Edition. St Louis: George Brooks, Time mirror/Mosby College publishing.

Prescott, LM. Harley, JP. and Kleins, DA., (2008). Microbiology:Treatment of Water. $11^{\text {th }}$ Edition. New York: McGram Hill Company.

Rwanda Bureau of Standards (RBS), (2011). Quarterly Newsletter, Issue 13 (online) $<$ Available at: http://www.rwanda standards.org/ rbs/fileadmin/user_uplo ad/files/Newsletter_Issue_no_13.pdf> [Accessed on $30^{\text {th }}$ March, 2012].

Roberts, D.. Hooper, W. and Greenwood, M. (1995). Practical food Microbiology. London: Public Health Laboratory service.

Simango, C., Dindiwe, J. and Rukure, G. (1992). Bacterial contamination of food and household drinking water in a farm worker community in Zimbabwe. Central African Journal of Medicine, 38(4):143-149.

Urbansky, E.T. and Magnuson, M.L. (2002). Analyzing drinking water for disinfection by product. Analytical Chemistry, 74(1): 261A.

World Health Organisation (WHO), (1998). Guidelines for drinking water quality, Health criteria and other supporting information. Geneva: WHO.

World Health organization (WHO), (2006). Guidelines for drinking water quality. Geneva: WHO. 